\title{
Plunder, Restitution, Emotion and the Weight of Archives: A Historical Approach ${ }^{\mathbf{1}}$
}

On March 31, 1955, ten years after the end of the war, the Council of Ministers of the Soviet Union announced its intention to return the artworks that had been removed from the Dresden Painting Gallery in 1945 and transported to the USSR. Two years later, in May 1957, the Central Committee of the Communist Party of the Soviet Union also decided to return the museum holdings that had been confiscated in Berlin. The following winter, from early September 1958 to mid-January 1959, hundreds of rail cars containing millions of artworks from Moscow and Leningrad arrived in East Berlin. For cultural life in Berlin and East Germany, this large-scale restitution was an unusually important event: for a whole decade, the special depositories where the Soviets kept the museum holdings from Germany had been totally inaccessible; the return of the artworks was meant to give impetus to the painstaking rebuilding of Museum Island, which had been destroyed by war. From November 1, 1958 until April 1959, the island was the setting for the exhibit Schätze der Weltkultur von der Sowjetunion gerettet (Treasures of the World Cultural Heritage retrieved from the Soviet Union). The exhibit, mounted with clear political intentions, marked the end of the 13-year exile of German artworks in Soviet depositories. However, it was far from the end of the so-called "looted-art debate" revolving around the artworks not returned by the Soviet Union.

In the 1990s, this debate developed into an affair of state between the then unified Germany and the no longer Soviet Russia. In a caricature by Horst Haitzinger in the Rhein Zeitung of April 17, 1997 (Fig. 5), an oversized Russian President, Boris Yeltsin, is depicted clutching his diplomat's briefcase, standing in front of a grotesque re-creation of the Laocoön sculpture that artfully embodies a naked Helmut Kohl in the center and two naked ministers, one on either side. The gigantic snakes they wrestle with are labeled "Pensions", "Budget”, “T'ax Reform", and "Billion-Mark Deficits". - So with all that what do you need our looted art for? the Russian president asks the antique sculpture. What is implied is that anyone who already has a Laocoön (or is able to

\footnotetext{
1 This contribution is a synthesis of thoughts that have come to mind in the course of writing various articles for publication and through participation in the conference Wie das zweite Exil das erste zum Sprechen bringt. Moskauer Archive und die Künste in Paris 1933-1945 in Moscow. For their inspirational role, I would here like to thank Ines Rotermund-Reynard (Paris), Gilbert Lupfer (Dresden) and Uwe Fleckner (Hamburg). See Bénédicte Savoy, An Bildern schleppt ihr hin und her ... Restitutionen und Emotionen in historischer Perspektive, in: Stefan Koldehoff, Gilbert Lupfer, Martin Roth (eds.), Kunst-Transfers. Thesen und Visionen zur Restitution von Kunstwerken, Berlin 2009, pp. 85-102; Bénédicte Savoy, Kunstraub, in: Martin Warnke, Uwe Fleckner, Hendrik Ziegler (eds.), Handbuch der Politischen Ikonographie, vol. 2, München 2011, p. 73-78; Bénédicte Savoy, Kunstraub. Napoleons Konfiszierungen in Deutschland und die europäischen Folgen, Wien 2011.
} 


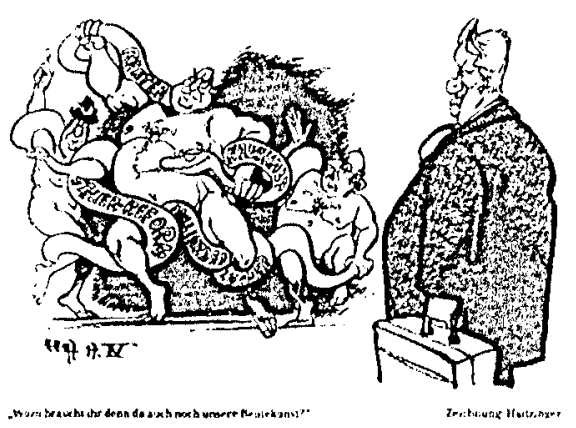

Fig. 5: Caricature by Horst

Haitzinger, in:

Rhein Zeitung, April 17th, 1997.

create one's own) should forego any further restitution of art treasures. Of course, it is common knowledge that the Laocoön sculpture was not at all one of the art treasures returned to Germany from the Soviet Union - it had been taken from Rome by the French 200 years before, to be returned in 1815 when Napoleon fell from power. But the striking persistence of Laocoön as a figurative reference to the subject of looted art indicates a deep-seated knowledge of such events lurking in the collective unconscious. This is only a recent example of the sustained, and not only visual memory on the part of victims of art theft and the wound of loss that is so slow to heal. The following is not meant to be an account of the looting and restitution of art works as an anthropological constant since antiquity - the subject is far too complex for such an undertaking. Rather, in the short space allotted, I will focus on the debate surrounding looting and restitution and give a brief summary of some of the recurrent issues to which it gives rise.

\section{Right and Revenge: The Long Life of Loss}

At some time in the eighteenth century B.C., or even in the nineteenth, the Elamite ruler Kutir-Nahhunte I abducted a Babylonian statue of the goddess of fertility and victory, Nanaya, and brought it to his capital. And at some point, after many centuries and a major military campaign, the statue came back to its country of origin. We know this thanks to the Assyrian king Assurbanipal, who retrieved the statue in the seventh century B.C. and memorialized the event in the following inscription:

"Nanaya, whose anger raged for 1635 years, Nanaya, who moved away and settled in Elam, a place unworthy of her, entrusted me with the mission of bringing her home."2

2 Walter Hinz, Das Reich Elam, Stuttgart 1964, p. 10. Cited from: Volker Michael Strocka, Kunstraub in der Antike, in: id. (ed.), Kunstraub - ein Siegerrecht? Historische Fälle und juristische Einwände, Berlin 1999, pp.9-26, here p. 10. See also J.-M. Aynard, Le prisme du Louvre 4019.939 [introd., autograph and transcription of the Assyrian text with French translation facing], Paris 1957. 
Between the looting of the statue and its return to Babylon, no less than 1300 years elapsed: ${ }^{3}$ an incredibly impressive example of the sustained memory of victims of art theft and of the slow-healing wound of loss.

Today, sixty-three years after the end of the Second World War, there are those who believe, perhaps rightly, that we should let the grass grow over some of the atrocities that then took place. But in the case of art looting, sixty years is obviously not sufficient. The wounds do not seem to want to heal. The public focus in Germany, for the last fifteen years, on art looted by the Russians in the Second World War, the constantly recurring controversy over the return of illegally acquired museum holdings previously belonging to Jews, the continual battles over the return of library inventories from Poland, the television programs with public participation discussing these subjects and so on, testify to the fact that cultural goods lost through war arouse collective emotions that are not mitigated by time. On the contrary, instead of mitigation, it would seem that historical distance tends towards rigidity, and rather than rapprochement, towards bitterness and distrust. The looted art of the past - not only that of the Second World War, since increasingly the "displaced objects" of the colonial period, objects that cannot really be subsumed under the term "looted art", are coming into focus - is certainly the greatest cultural-political challenge of the future, at least of the twenty-first century. ${ }^{4}$ It is thus all the more surprising that little historical depth has developed in relation to this subject, despite the fact that in the last five years new publications and above all, a series of historical exhibits worldwide (Paris, Stockholm, Moscow, Berlin) have shed new light on the subject. ${ }^{5}$

3 On this number, see Strocka 1999 (as fn. 2), p. 10.

4 See Hermann Parzinger, Archäologie und Politik. Eine Wissenschaft und ihr Weg zum kulturpolitischen Global Player [Gerda Henkel Vorlesung], Düsseldorf 2012.

5 Pierre Rosenberg, Marie-Anne Dupuy (eds.), Dominique-Vivant Denon. L'Oeil de Napoléon, exh. cat., Musée du Louvre, Paris 1999; Sigrun Paas, Sabine Mertens (eds.), Beutekunst unter Napoleon, exh. cat., Landesmuseum, Mainz 2003; Wilfried Menghin (ed.), Merowingerzeit - Europa ohne Grenzen. Archäologie und Geschichte des 5. bis 8.Jahrhunderts, exh. cat., Staatliches Puschkin Museum der Schönen Künste Moskau, Berlin/Wolfratshausen 2007; Ann Grönhammar (ed.), Krigsbyte $=$ War-Booty, exh. cat., Livrustkammaren, Stockholm 2007; Isabelle le Masne de Chermont, Laurence Sigal-Klagsbald (eds.), A qui appartenaient ces tableaux?, exh. cat., Musée d'Israël Jérusalem and Musée d'Art et d'Histoire du Judaïsme Paris, Paris 2008; Inka Bertz, Michael Dorrmann (eds.), Raub und Restitution. Kulturgut aus jüdischem Besitz von 1933 bis heute, exh. cat., Jüdisches Museum Berlin und Jüdisches Museum Frankfurt/M., Göttingen 2008. On the historical aspects of art looting, see Christina Kott, Préserver l'art de l'emnemi? Le patrimoine artistique en Belgique et en France occupées, 1914-1918, Paris 2006; Christoph Roolf, Die Forschungen des Kunsthistorikers Ernst Steinmann zum Napoleonischen Kunstraub zwischen Kulturgeschichtsschreibung, Auslandspropaganda und Kulturgutraub im Ersten Weltkrieg, in: Yvonne Dohna (ed.), Ernst Steinmann, Der Kunstraub Napoleons [1916], Rom 2007 (Veröffentlichungen der Bibliotheca Hertziana [Max-Planck-Institut] in Rom), pp. 433-477, online resource: http://edoc.biblhertz.it/editionen/steinmann/kunstraub (accessed April 2014), as well as the lectures in Section 19, Restitution, of the International Committee of the History of Art in Nuremberg, 2012. 
It is well known that in antiquity the looting of ritual and art objects was common practice. ${ }^{6}$ It is also firmly anchored in the general consciousness that the sometimes brutal, massive, and irrevocable acquisition of the cultural objects of foreign peoples has also led to impressive cultural and historical cross-pollination (not the least in ancient Rome). But it is certainly worthy of note that already in antiquity both the theme of retribution for art theft and that of return - the restitution of the original conditions - played a key role.

In Agamemnon, the first part of the Oresteia by Aeschylus of the fifth century B. C., there is a general reference to the dangers to which plunderers of ritual objects and foreign treasures expose themselves. At the beginning of the play, Clytemnestra warns against the fatal consequences that would be wrought on the victors if they were to loot the treasures of Troy:

The lords of Troy, tho' fallen, and her shrines;

So shall the spoilers not in turn be spoiled.

Yea, let no craving for forbidden gain

Bid conquerors yield before the darts of greed.

For we need yet, before the race be won,

Homewards, unharmed, to round the course once more. ${ }^{7}$

The message is clear: if the victors do not respect the temples of the vanquished, and if in addition to victory they take spoils, they will be subject to the gods' revenge. Here the cultural value of the coveted objects is central. The abducted, personified gods inflict vengeance or - as in the above-mentioned case of the goddess Nanaya entrust the task of retrieval to a powerful mortal. Human time is of no import in such affairs - only the eternal time of the gods holds sway, and the memory of the violation of the sacred is cultivated and carried on from generation to generation.

But, one might very well ask, what do such events in antiquity, where the ritual value of the plundered objects is the heart of the issue, have to do with the modern theft of works that have been transported from the capital city of the defeated to that of the victors because of their artistic value, their aesthetic, and certainly also monetary, value? The similarity between these two forms of theft - which at first we might not want to think of in the same way for historical reasons - becomes clear when we note the iconographic (rather than the discursive) forms of their transmission. In many cases, remembered narratives and emotions are more strongly linked with visual affects and the symbolic content of images than they are with justifications in prose.

6 Strocka 1999 (as fn. 2), p. 20.

7 Aeschylus, Agamemnon, transl. E. D. A. Morshead, online resource: http://classics.mit.edu/Aeschylus/agamemnon.html (accessed March 2013). 


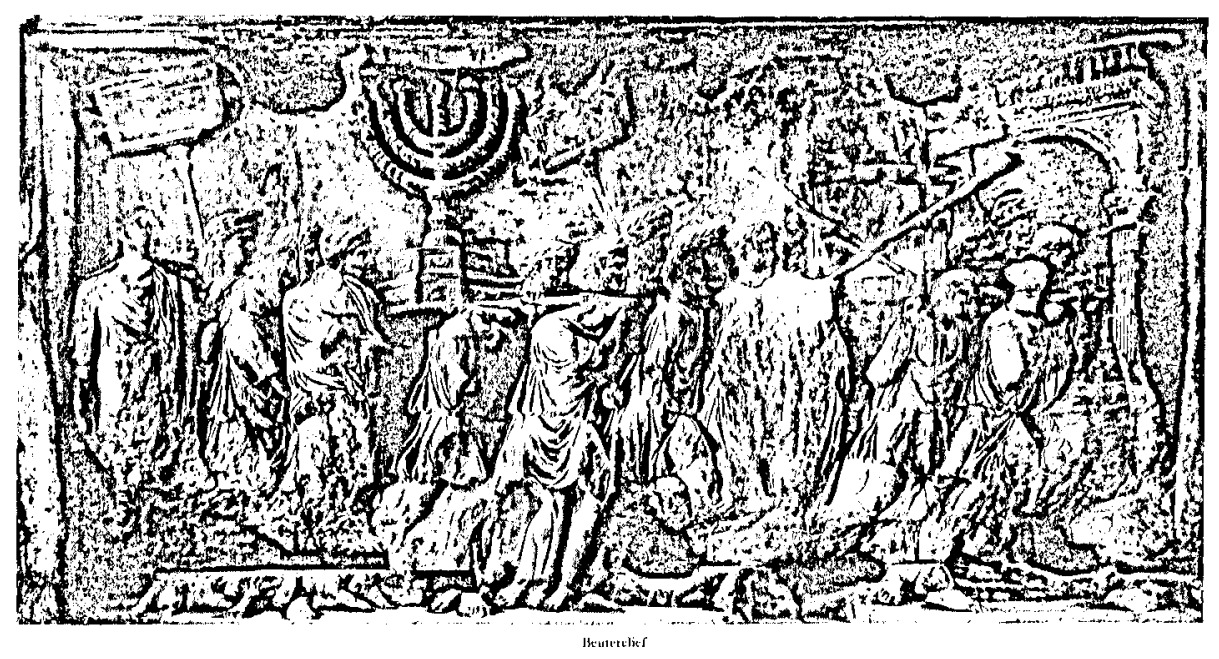

Fig. 6: Rome, Arch of Titus, c. $82 \mathrm{AD}$, Forum Romanum (OR: Unknown artist: Spoils of War relief, Marble, $200 \times 390 \mathrm{~cm}$, Rome, Forum Romanum.

One of the earliest, most visible, and impressive iconographic records of the ancient practice of art theft is certainly the so-called Spoils of War relief lining the passageway of the Titus Arch in Rome (Fig. 6). ${ }^{8}$ This monumental work was created at the end of the first century A. D. to memorialize the conquest of Jerusalem by Emperor Titus in the year 71. The Spoils of War shows a group of life-size soldiers bearing sumptuous plunder marching in procession through an arched monument crowned by tiers of horses. To emphasize the heavy weight of the booty and thus the great value of the plundered objects, the men have been yoked with shoulder poles - eight to a pole. The triumphantly carried objects had previously been displayed in the Temple of Jerusalem and were thus ritual objects: two sacred trumpets, a showbread table, and above all, the seven-branched candelabra, the menorah. Anything having to do with landscape or random detail has been minimized. The plunder is the central visual attraction and the relief can be read as a message: plunder and the arched monument characterize the triumph of Emperor Titus.

Some eighteen centuries later, in 1813, during the Napoleonic Era, the iconography of the Titus Arch emerged in the French memory. Dominique-Vivant Denon, known as "Napoleon's eye," commissioned a magnificent Sèvres porcelain showpiece vase. It clearly shows the permanent nature of the pictorial semantics of art theft, despite any change there may have been in the function of art or the updated legitimizing

8 See Martin Warnke, Uwe Fleckner, Hendrik Ziegler (eds.), Handbuch der politischen Ikonographie, 2 vols., München 2011. 
rhetoric surrounding the issue. The vase, too, memorializes the arrival in Rome in 1796 of looted artwork from France: the Laocoön and His Sons, the Apollo Belvedere, the Venus de' Medici, all considered iconic works of antiquity at the time, loaded on low, open carts, pass by obviously impressed observers in bourgeois dress. Between the carts, various groups of men bear further plunder pieces on carrying-poles, the most obvious transporting objects on their shoulders. Books and manuscripts are also being carried in triumph: among these, rolls reminiscent of the Torah. The picto rial reference to the Spoils of War relief on the Titus Arch is unmistakable. With just one exception: whereas the antique procession of plunder is shown passing through a triumphal arch crowned by horses, the modern art plunderers are crossing under an archway with the following inscriptions. On the left we see: "Musée Napoléon", and on the right, simply "Musée" (Pl. III). The victory of the fledgling institution could not be expressed more unequivocally. The translatio imperii (transfer of rule) has beet undertaken in favor of the general, bourgeois public, the translatio studii (transfer of learning), dressed in consequence. The museum has triumphed.

Making its way into the collective unconscious on a visual and symbolic leve] was the motif of triumph and the concomitant humiliation of those who had been despoiled. In that context, whether people were robbed of their religious identity (in antiquity), or of their identity as individuals of the Enlightenment who considered Art as a means of education and advancement (around 1800) is of little import. Furthermore, since the end of the eighteenth century, art had been the object of a secularized religion: the religion of Art, whose temple was the museum. So far as art theft is con. cerned, since the time of antiquity, works of art, surviving over countless generations, had been valued for their enduring quality far more than for any cultic or educational significance they may have had. This explains the tenacity of the emotions arising from such a loss.

Indeed, the theft of artworks and looting of libraries are not just illegal acts, they also inflict emotional wounds that heal only with great difficulty or not at all. Karl Heinrich Heydenreich, professor of philosophy in Leipzig, expressed this fact as early as one hundred years before the Hague Convention in a juridical article of 1798 on the occasion of the French army's transport of Italian works of art to Paris. His article was entitled, "Is the conqueror of a vanquished people allowed to rob them of works of literature and art? A Human Rights question". 9 When a victor wrests "works of art and literature from a vanquished people," Heydenreich writes in this text, still very much worth reading today, then in principle he is communicating the following message:

9 Karl Heinrich Heydenreich, Darf der Sieger einem überwundenen Volke Werke der Litteratur und Kunst entreißen? Eine völkerrechtliche Quästion, in: Deutsche Monatsschrift [9] (Aug. 1798), pp. 290295. 
"From now on, you will be less able and it will be more difficult to become a learned man, the models for genius and taste that lead to immortality will be wrested from the noblest of your sons; the beautiful figures of art, which inspire human and amiable feelings throughout the nation, are to remain forever hidden from your gaze." ${ }^{10}$

And Heydenreich continues:

"And I can do nothing but declare it a crime against humanity if a defeated nation is robbed of its national masterpieces of art. For the nation itself, these are priceless; for their true value allows of no comparison." 11

"[The victor], in doing so, announces the immortality of his hatred and revenge; for as long as the vanquished nation exists, so long will last its shame, in the face of a loss that is irreparable over centuries without end." 12

\section{Administrations and Emotions}

In the light of this background, it is significant that since the fourth century B. C. there have been cases of spectacular restitutions of art objects removed from their place of origin and returned after many decades, even centuries. ${ }^{13}$ Thus for example, it took 150 years for the Harmodius and Aristogeiton statue pair, a monument essential to the identity of the city of Athens, to be returned by Alexander the Great after having been abducted to Persia during the Persian Wars. ${ }^{14}$ Another example: after the Romans took over Carthage in the year 146 B. C., they scoured the city for all the works of art that Carthage had taken from Sicily 300 years before in order to make sure, according to Cicero, that "every Sicilian community would get back its property." 15

What was behind such restitutions is easy to surmise. By returning works of art and ritual objects pillaged in war, the new rulers were seeking to demonstrate their concern for the needs of their subjects - and thus win their loyalty. This more or less politically motivated restitution of stolen cultural property is one of the most enduring constants in the history of art-looting from antiquity to the Napoleonic era and all the way to the twentieth century. Abundant sources, not the least of iconographic nature, testify to this fact. Thus for example, the depiction of the return to Venice of the Bronze Horses of Saint Mark's, which France had transported to Paris in 1797 and

\footnotetext{
10 Ibid., p. 293.

11 Ibid., p. 294.

12 Ibid.

13 See Strocka 1999 (as fn. 2).

14 See ibid., p. 13.

15 Cicero, in: C. Verrem 2, 4, 73. Manfred Fuhrmann (ed.), M. Tullius Cicero, Die Reden gegen Verres, latin/german, vol. 2, Zürich 1995. Cited from Strocka 1999 (as fn. 2), p. 19.
} 


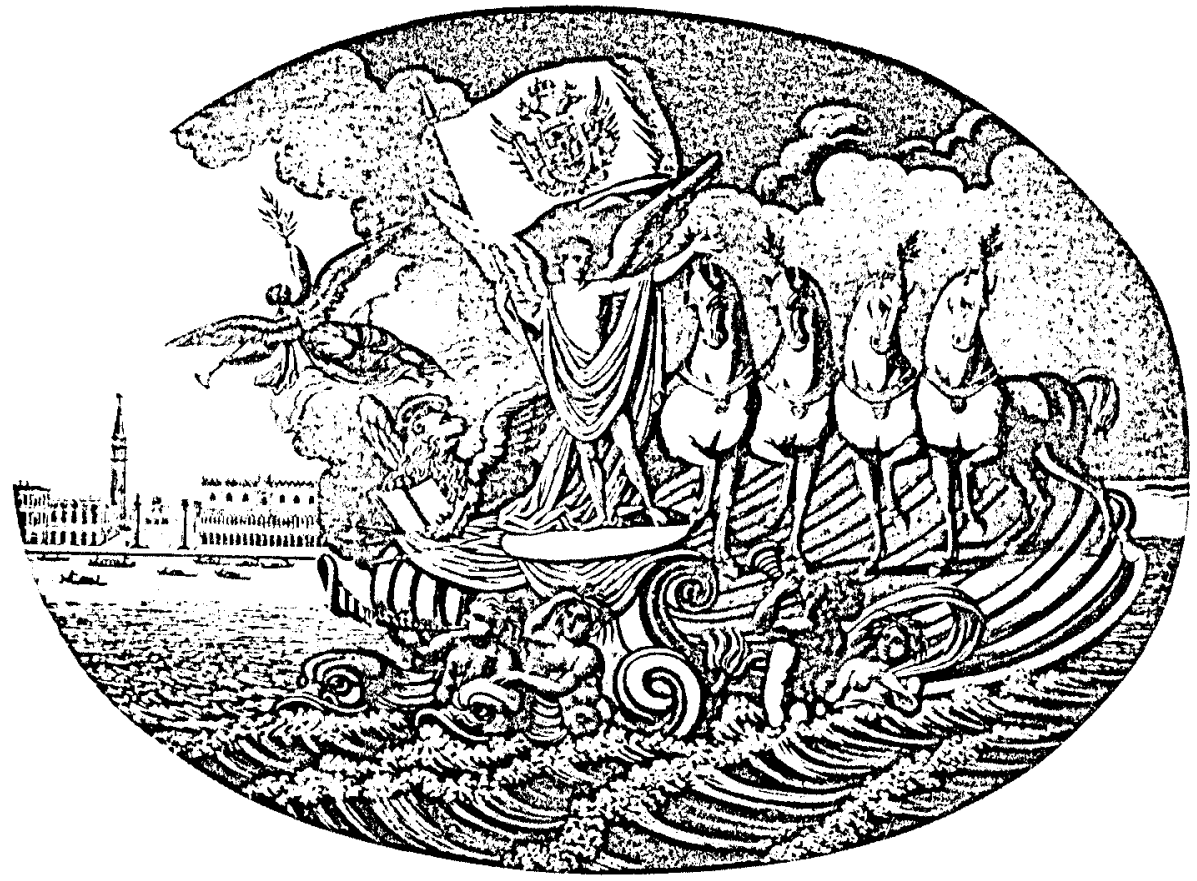

Fig. 7: Apotheosis of Francis / of Austria, allegory of the return of the Horses of Saint Mark's to Venice in 1815 , etching, $37,6 \times 48,5 \mathrm{~cm}$, Venice, Museo Correr.

which Austria then returned to Venice in 1815 (Fig. 7). Or this photograph from the summer of 1945, documenting the festive return of evacuated works of art to Florence (Fig. 8). A convoy of American trucks is entering the city. Four trumpeters sound a welcoming salute. The first motor vehicle is loaded with large wooden crates containing artworks that a few months before, the so-called "art protection division" (Kunstschutz) of the German Wehrmacht - with whatever intentions - had transported from Tuscany to Southern Tyrol. ${ }^{16}$ Italian and American flags decorate the vehicle along with a clearly visible sign reading, Le opere d'arte fiorentine tornano dall'Alto Adige alla loro sede (Florentine artworks returning home from Alto Adige). The original - rejected - suggestion for the sign had been: "Florentine treasures, stolen by

16 See Rodolfo Siviero, LArte e il Nazismo. Esodo e ritorno delle opere d'arte italiane 1938-1963, Firenze 1984; Christian Fuhrmeister et al. (eds.), Kunsthistoriker im Krieg. Deutscher Militärischer Kunstschutz in Italien 19:43-1945, Köln/Weimar/Wien 2012 (Veröffentlichungen des Zentralinstituts für Kunstgeschichte, vol. 29), with bibliography. 


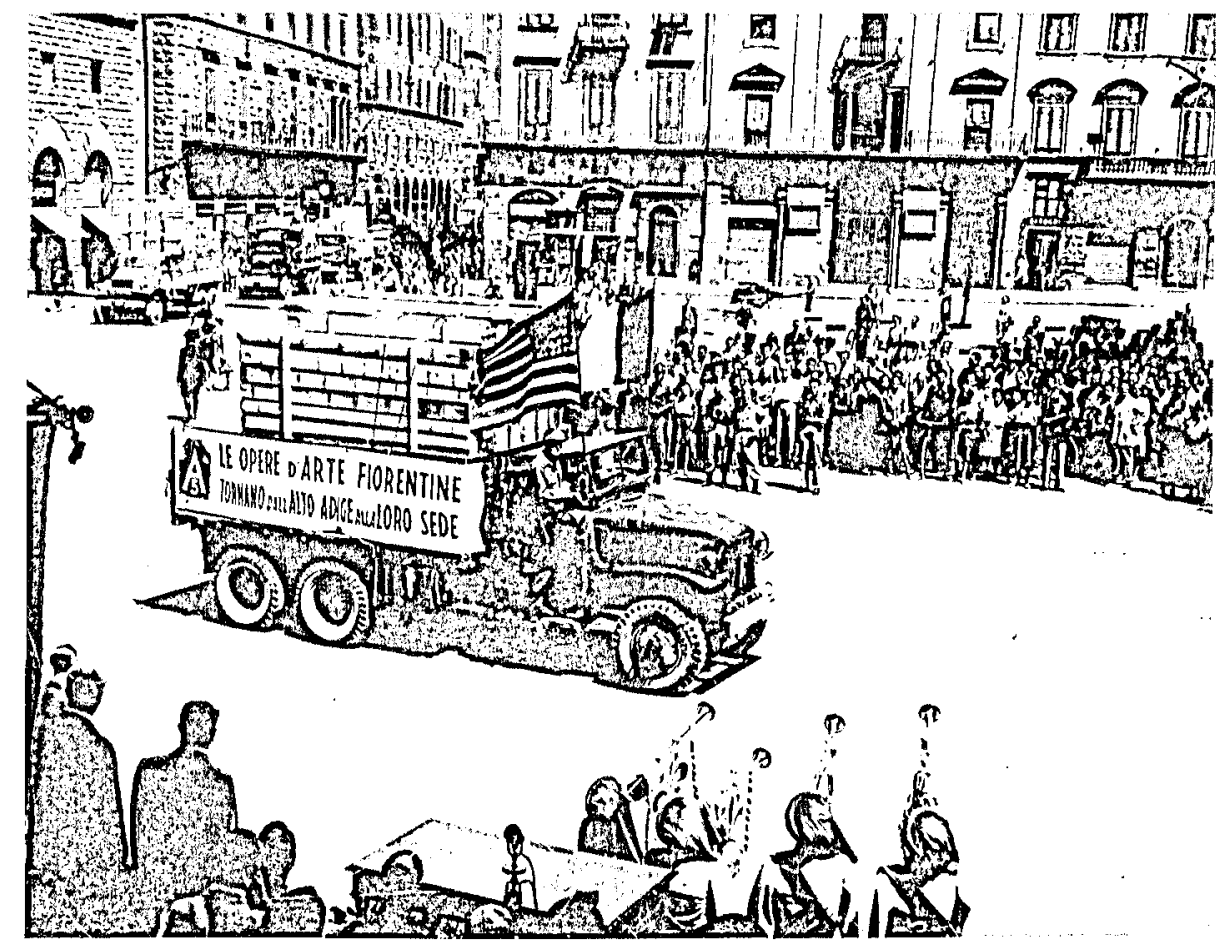

Fig. 8: Festive return of evacuated works of art to Florence, July 21st, 1945, (Unknown photographer).

the Germans, are returned by the Americans." ${ }^{17}$ Here, as in the case of the Venetian horses, the role of the rescuer is linked with the motif of restitution; at the same time however, light is shed on the gray area between theft and rescue, responsible salvaging and aggressive acquisition of art treasures in times of war.

But what emotional consequences do we find when we examine the restitutions which never took place, especir' 'ly from the perspective of those (public officials, scholars, etc.) who in the past had to deal with formulating (unsuccessful) claims? It was never a matter of course for art historians, museum officials, or librarians - even one or two hundred years ago - to be involved in current political affairs. And certainly not in a way that would result in their scholarly work having concrete political consequences. The best example of the apprehension an affair of restitution aroused in a prominent scholar is surely that provided by Jacob Grimm. In 1815, he was sent as a Prussian legation secretary to Paris, where he was supposed to reclaim and accept

17 Cited from Ernst Kubin, Raub oder Schutz? Der deutsche Militärische Kunstschutz in Italien, Graz 1994 , pp. $128 \mathrm{ff}$. 
the delivery of manuscripts from the Rhineland and paintings from Kassel. He had been chosen for the assignment, among others, because of his intimate acquaintance with the manuscript department of the Bibliothèque Nationale, where in previous years, he had done research for months at a time. In a letter to his brother, he wrote about his function in the restitution commission in the summer of 1815:

"It is personally awkward for me, not only because there is always something distasteful about tracking down and taking away something out of the established order, but because I am now confronting people who have previously been helpful and courteous to me. If they now reproach me for this - and they do so - then my conscience is relieved by the fact that what I am supposed to do has a higher purpose than any obligations incurred by such services: but I do wish that I had not been needed for this task."18

Already in the years 1814-1816, when the fall of Napoleon made the recovery of stolen property possible, almost exhaustive documentation facilitated the repatriation of painting and antique objects to Germany; the confiscation of rare prints and manuscripts, however, had not been completely documented, and thus there were hardly any returns. The commission responsible for finding such works complained early on of being dependent on chance. For example, the young Prussian commissioner from the Rhineland, Eberhard von Groote, who in 1815 dealt with this issue for Prussia on a voluntary basis, wrote:

"It was much easier for the directors to hide the more rare objects and to deny they had them, than for us to search through the catalogues, which completely filled the many compartments of the bookcases, to find what was missing. [...] and we would have left empty-handed had good luck and ruse not procured one thing or the other for us." ${ }^{13}$

Good luck and ruse on one side, and the uncooperative attitude of the French conservators on the other: from the very beginning, the acquisition of information and the speculation that important evidence was kept inaccessible in France played a central role.

It is interesting though, that one hundred years later, during the First World War, this situation arose once again. ${ }^{20}$ At that time, under the directive of the Prussian

18 Heinz Rölleke (ed.), Briefwechsel zwischen Jacob and Wilhelm Grimm, part 1, text, Stuttgart 2001 (Briefwechsel der Brüder Jacob und Wilhelm Grimm, Kritische Ausgabe in Einzelbänden, vol. 1.1), p. 461. See Savoy, Kunstraub 2011 (as fn. 1), p. 256 f.

19 Eberhard von Groote, Die Wegnahme der durch die Franzosen geraubten Kunstschätze in Paris. 1815. Aus dem Tagebuch eines Preuß. Freiwilligen, in: Agrippina. Zeitschrift für Poesie, Literatur, Kritik und Kunst [1] (Feb. 22 - Mar. 24, 1824), pp. 93-146, here p. 134.

20 See Roolf 2007 (as fn. 5); Bênédicte Savoy, Krieg, Wissenschaft und Recht. Die Erinnerung an Napoleons Kunstraub um 1915, in: Osteuropa 56, nos. 1-2 (2006), special issue Kunst und Kultur im Schatten des Krieges. 
Ministry of Culture, many renowned library and museum personnel were researching the art thefts that had occurred under Napoleon. More than a century had passed, but time had erased nothing. A whole generation of museum curators and librarians were devoting themselves enthusiastically to the search for artworks, books and manuscripts presumed to be in Paris. Even today, many institutions west of the Rhine possess comprehensive records and archival estates from the years around 1915 that document this research activity. They show how national myths and attitudes have always marked the debate around the looting of art.

These scholars, adhering to an imposing tradition of outstanding erudition, conducted their meticulous research with a double objective. One one hand, carefully considered historic positions and precise, top-secret lists of lost items were to serve as a basis for the reclamations. On the other hand, the investigators - under the directive of the Prussian Ministry of Culture or the so-called Central Office for Foreign Service (Zentralstelle für Auslandsdienst), a department responsible for war propaganda in Berlin - were also in charge of drafting countless lectures and articles for general public consumption on the topic of Napoleonic art theft. The materials that came together in the course of these activities now offer a lively picture of the way in which a small, elite group of scholars, museum personnel and librarians, caught between political deliberations and the need to process what had occurred, dealt with this great trauma.

Obtaining information was also a methodical challenge. One can easily imagine the conflict of interests - the "victims" wanted to access, and the "perpetrators" to hide information that had been under lock and key for a century. In the German-French case, the problem was to find information that was reliable. Thus for example, the librarian Hermann Degering investigating the French book thefts around 1800 at the Berlin State Library, wrote: "If the relevant files that exist in Paris were accessible to us, we would be able to see much more clearly than is possible today, down to the minutest details, a situation which, due to the patchiness of our source materials, makes us dependent for large areas solely on suppositions and on conclusions based on analogies."21

Still today, this kind of nagging uncertainty causes the issue of looted art to remain a hotbed of dire legends. Around 1915, the compilation of a German catalogue of losses was not the only interest at stake. There was also the major, fundamental question arousing passions all over Europe - the supposed struggle of civilization against barbarism. In August 1914, no lesser a figure than the philosopher Henri Bergson declared that the war against Germany was "the war of civilization against barbarism, per se." In the back and forth of vilification and blame, the German side saw Napoleonic art theft as a paramount example of the inferiority of French culture:

21 Undated account by Hermann Degering, Berlin, Staatsbibliothek Preußischer Kulturbesitz, Manuscript department, NL Degering, unordered fragments. See Savoy, Kunstraub 2011 (as fn. 1), p. 300. 
"It is inexpressible how ignorance and barbarity raged against the masterpieces of painting in Belgium ... When it was decided which Belgian masterpieces would be transported to Paris, $\mathrm{tl}_{\mathrm{l}}$ order was given to take down the paintings and pack them. What did the barbarians do up $\mathrm{h}_{\mathrm{n}}$ receiving this order? They leaned a ladder against the painting and cut it into strips with the ir knives and sabers ... Numerous paintings by Rubens were subjected to such mistreatment."22

So Steinmann wrote in his account of the French confiscation campaign of $1794 . Q_{n}$ the French side, it was the allies' re-appropriation of looted artworks in 1815 in Par $_{\text {is }}$ that was an occasion for similar denunciating, anachronistic outbursts. In 1915, for example, the highly esteemed specialist in German studies Arthur Chuquet wrote:

"In 1815, those were the demands of that greedy, insatiable Prussia! [...] In 1815, the Prussia hs [...] plundered our museums with no inhibitions. [...] If it had been possible, Prussia would have stolen even more. Its arrogance was incomparable and its language of 1815 reminds us of its language in 1914." ${ }^{23}$

Anyone, be they French or German, reading such reports of the years 1914-1918, will learn more about the First World War than about Napoleonic art looting - just as we, in today's discussions on looted art, learn more about our mutual compulsions and woun $\mathrm{ds}_{\mathrm{s}}$ where conflicts between nations and emotions are concerned, than about objects of the European cultural heritage scattered this way and that across the continent.

\section{Changed Art Geography and the Project of European Civilization}

Today, preserved in the Berlin State Library, is a fourteenth century manuscript that Jacob Grimm, under the authorization of the Prussian government, secured from the Paris National Library in 1815. On the cover page, the young legation secretary and claims commissioner commented in his own hand: "Manuscript originally from Blankenheim, transported to Paris by the French and finally returned to Prussia. Paris, October 14, 1815. Grimm." "24 On the next to last page of the same manuscript is a depiction of the wheel of Fortuna, the antique goddess of fortune and the personification of fate. Perpetually turning, Fortuna's wheel tosses humans and objects to and fro throughout the world (Fig. 9). The image is seen in a delicate contour drawing, con-

22 Dohna 2007 (as fn. 5), p. 26.

23 Arthur Chuquet, Les Prusses et le musée du Louvre en 1815, in: Revue des sciences politiques 36 (1916), pp. 264-294, here pp. 291-293. See Savoy, Kunstraub 2011 (as fn. 1), p. 290.

24 [Sächsische Weltchronik], Staatsbibliothek Berlin, Ms. germ. qu. 284, see Hermann Degering, Kurzes Verzeichnis der germanischen Handschriften der preussischen Staatsbibliothek, vol. II, Leipzig 1926, p. 50. 


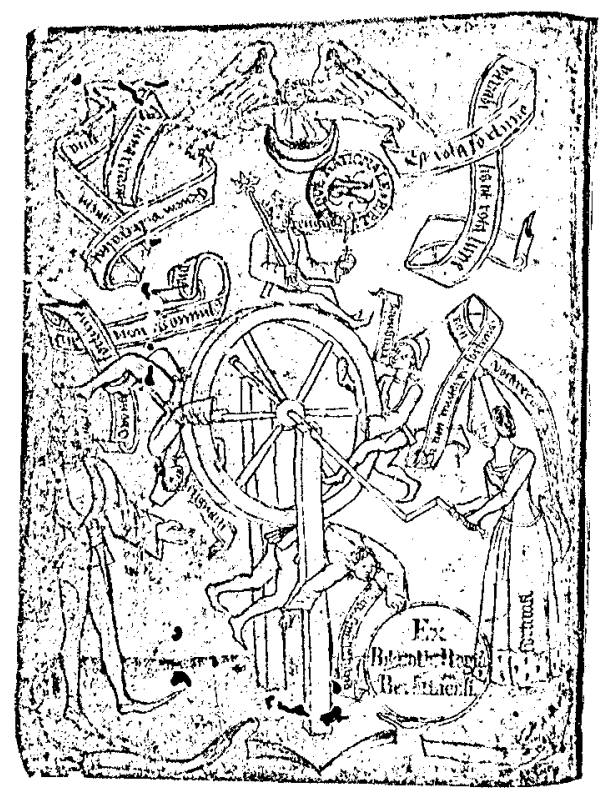

Fig. 9: [Sächsische Weltchronik] Manuscript that was sent to Paris by Maugérard; Berlin, Staatsbibliothek Preußischer Kulturbesitz, Handschriftenabteilung, Ms. germ. qu. 284, fol. $197 \mathrm{v}$.

spicuously marked by two red stamps. Above: Bibliothèque Nationale Paris. Below: Royal Library Berlin - two scars that simultaneously make the page into a wonderful allegory for the fate of books and artworks in critical times. The manuscript is special not only for this allegorical value, with which it surely can be credited, but also for the fact that though it was confiscated by the French authorities in the Rhineland, in Blankenheim south of Bonn, it was returned in 1815 not to the Rhineland but to Prussia - to Berlin, the new capital of the province. It is just one example among many of what happened to hundreds of works of art in the cities that went to Prussia after 1814 (in Danzig there are further spectacular cases from this time). Consequently, the restitutions of 1815 in the German-speaking regions were the occasion for often heated discussions on the appropriate way to reconfigure Germany's cultural landscape - and that of Europe - after the Napoleonic experiment of maximal centralization, in Paris, of Europe's cultural heritage. The Prussian government assigned no lesser a figure than Johann Wolfgang von Goethe to issue a statement concerning the new distribution of artworks that in the course of restitution had been awarded to Prussia. Why Goethe? In the years from 1796 to 1800 , he had taken on a prominent position in the German chorus of voices against the removal of artworks from Italy and their transport to Paris. In that context, he had spoken of an act of "ripping out," a deed he perceived as direct aggression against the intellectual world of the eighteenth century. For Goethe and the enlightened circles of the eighteenth century, Rome was a kind of "capital of the world", as Goethe called it, a city with a unique international cultural community, where the artworks and antique ruins were thought of as the common cultural heri- 
tage of humanity. This cosmo-political ideal of the eighteenth century was called into question by the appropriation practices of the French: to vindicate their confiscations in other countries, they no longer considered art the property of humanity but represented it rather as a product of liberty. Consequently, in theory, "liberated" France saw itself as the rightful heir to all of Western culture - thus from the German point of view, as the "general leaseholder" of civilization. An absolute antinomy thus appeared between cosmopolitanism and nationalism. In the eyes of the Germans, the barbarians were those who would substitute a new, national model, for European cosmopolitan thinking on art - until then considered the ideal of civilization.

On the basis of his previous positions then, Goethe was asked to formulate his opinion on the distribution of the art treasures recovered in Paris by Prussia - an opinion which was basically a statement that transcended the boundaries of the Rhineland to the issue of whether works of art should be concentrated in one place or spread out over a whole territory. The collector Sulpiz Boisérée commented on this in his diary: "Visited Goethe at noon and had a cheerful, cordial reception. Stein had asked him to write a memoir to Hardenberg on art and antiquarian subjects; he wanted to ask my advice about it. [...] The premise will be that works of art and the antiquities should be widely distributed, that every city should receive and retain its own works, with the stipulation that the whole should be overseen by a centralized authority. Let Düsseldorf have some of its things in the original positions they were once displayed in. Why should Munich have it all? Let Cologne, Bonn, and, yes, Andernach, have some, as well! It is wonderful and a great example that the Prussians are returning St. Peter to Cologne." ${ }^{25}$ With this attitude, Goethe - and he was not the only one in 1815 who was pleading for a "scattering" - had positioned himself firmly against the spirit of the nineteenth century, which advocated the consolidation of what was then perceived as "national" cultural heritage in just a few monumental museums in Europe's capital cities. It was a discussion that is highly relevant today in consideration of the holdings of German looted art in far-flung provincial museums of the former Soviet Union. ${ }^{26}$ As early as August 1815, the patriotic Rheinische Merkur brought the argument to a head: "In art, it is the scattering, the works of art strewn like stars across the heavens that is exhilarating and invigorating, while the aggregation of works only leads to opulence and aesthetic luxury."27

In 1915, when Fritz Milkau, the then director of the university library in Breslau, heard of German plans to retrieve the manuscripts from Paris, he wrote the following sober

25 Sulpiz Boissérée, Tagebücher 1808 -1854, 5 vols., Darmstadt 1978-1995, here vol. I, 1978, p. 224. See Savoy, Kunstraub 2011 (as fn. 1), pp. $251 \mathrm{ff}$.

26 See Kerstin Holm, Rubens in Sibirien - Beutekunst aus Deutschland in der russischen Provinz, Berlin 2008.

27 Rheinischer Merkur, Aug. 6, 1815, no. 279, p. 2, col. 1. See Savoy, Kunstraub 2011 (as fn. 1), p. 252. 
words to the director general of the Berlin State Library: "I cannot seem to get rid of the idea that war is followed by peace, and that when seen in the larger scale of things, the reconstitution of international communication between libraries is more important than the inconsequential relocation of some manuscript holdings." 28 This courageous position, taken in the context of the heated nationalistic and propagandistic atmosphere of the First World War, is like an echo of Goethe's famous quatrain Museen, composed in 1816 in the midst of the restitution debate that went on in the years after the Congress of Vienna:

"An Bildern schleppt ihr hin und her

Verlornes und Erworbnes

Und bei dem Senden kreuz und quer

Was bleibt uns denn? Verdorbnes!"29

And Victor Hugo reacted with the following words on the plundering of Peking in 1861:

\begin{abstract}
"One day two bandits entered the Summer Palace. One plundered, the other burned. Victory can be a thieving woman, or so it seems. The devastation of the Summer Palace was accomplished by the two victors acting jointly. [...] What a great exploit! What a windfall! One of the two victors filled his pockets; when the other saw this he filled his coffers. And back they came to Europe, arm in arm, laughing away. Such is the story of the two bandits. We Europeans are the civilized ones, and for us the Chinese are the barbarians. This is what civilization has done to barbarism. [...] I hope that a day will come when France, delivered and cleansed, will return this booty to clespoiled China." ${ }^{30}$
\end{abstract}

Whether poetically in 1816 or polemically in 1861, or bureaucratically in 1915, the problems of those who have gone before us are no different from our own.

\title{
A Problem of Civilization
}

As is evident to those involved in historical cases of looted art, restitution, and the legends and passions they arouse, the careful and transparent documentation of

28 Berlin, Staatsbibliothek Preußischer Kulturbesitz, Dienstakten Iil C 1, vol. 23, fol. 45. Letter from Milkau to Harnack, from Brussels, Jun. 12, 1815. See Savoy, Kunstraub 2011 (as fn. 1), p. 297.

29 Johann Wolfgang von Goethe, Museen, in: Goethes Werke [W $\Lambda$ ], Weimar 1887-1919, here section I, vol. 3, Weimar 1890, p. 121. (You're carting pictures left and right/Lost ones, got ones, to and fro/ What's the object of the flight?/Rotted, ruined tableaux!) [transl. J. A.].

30 Victor Hugo, Actes et paroles, CEuvres complètes, politique, Paris 1985, pp. 527-528, lettre au capitaine Butler, 25 novembre 1861. Transl.: www.napoleon.org/en/reading_room/articles/files/477511.asp (accessed April 2013). 
each individual case is of prime importance. Experience has shown that incomplete documentation of a specific case, or rumors and suppositions about the presence or absence of particular works in the museums or libraries, all create fertile ground for passionate rhetoric, polarized attitudes, and confrontation (see article by Ines Rotermund-Reynard in this volume). This concerns first of all and to a high degree the whole problem of the confiscation of Jewish art collections during the Second World War (under the heading "Provenance") as it does the question of the cultural objects subjected to so-called "wartime displacement" in Central and Eastern Europe during the Second World War. But increasingly, it also concerns the question of how "Western" museums deal with the objects - archaeological and ethnographic objects in particular - which came into their hands during the colonial era. To give just one example: it took the Berlin museums almost one hundred years after the transport of the Nefertiti bust from Egypt to Berlin - and no less than the pressure of an external, non-museum study - to finally enable public access to the archival documents that traced the presence of the controversial bust so far north of its place of origin. ${ }^{31} \mathrm{~A}$ very long time - along with all the political consequences, well covered by the media, that arose from this institutional "silence."

Seen against this background, archives are a kind of central nervous system enabling us to reconstruct the archaeological layers of human lives or works of art. These archives need to be used, and must be useable. Their users should not be, as has been the case so far, mainly provenance researchers, legal advisors and lawyers with their own particular interests, but by all means and far more frequently than until now, historians and art historians, intent on uncovering the complexities of the events and all their implications (cultural, political, economic, emotional, for the history of memory, etc.). Archives should not only be open, but made useable and should be used, so as to further transparency and objectivity in these questions. If they remain closed, or are used only by those who functionalize them for political, legal, or economic ends, the result can be a reopening of old wounds and the triggering of phantom pain among those who have been robbed - even leading to acts of revenge. As mentioned above, the German historiography of the Napoleonic art theft is a case in point. With no access to the French documentation - for decades of the nineteenth century - such a degree of frustration developed that in the First World War the practice of confiscating artworks and books was reignited and took on characteristics of revenge. An uncompromising elucidation of provenances and easy access to all art and archival holdings - including "foreign" property - must be a priority of our generation. This is irrespective of the question as to whether objects should be restituted or not - in many cases (including Nefertiti, looted documents in Moscow, etc.), the answer may very well be that 100 or 200 years of archival, museum,

31 Friederike Seyfried, Die Büste der Nofretete. Dokumentation des Fundes und der Fundteilung 1912/1913, in: Jahrbuch Preußischer Kulturbesitz 46 (2010, publ. 2011), pp. 133-202. 
or library history cannot be reversed as if nothing had transpired, i. e. that in the course of their eventful lives, the objects have acquired a double identity: that of their place of origin and that of their adopted land.

\section{Actively into the Archive}

The above reflections make clear that art and cultural historians in particular need to recognize the subject of "displaced objects" as an objective, non-emotional focus of research. Until the 1990s, the provenance of an artwork played a central role among art historians and museum officials, but a very abstract one in the sense of, a kind of finger exercise for Catalogues raisonnés and the like (history of previous ownership). The "political" history of an artwork, so to speak, was never particularly of interest to museums, auction houses, or art historians, etc.: they never really had to be interested, or, as in the case of West Germany, were concerned mainly with their own losses. In fact, museums and art historians were never really interested in anything but the artist and the present owner, or in the interpretation or exhibition of a work of art. Since the restitution claims of the 1990s however, the material and political history of the holdings has emerged in institutions concerned with art. The pressure to investigate this history comes from without, not from the art world and certainly not from the institutions in possession of the objects in question. In France, for example, it was a provocative cover page of $L e$ Monde that prompted the museum to take action in 1996. It must be recognized that the debate about looted art, restitution, provenance, etc., has genuinely transnational, interdisciplinary dimensions. Historians, and art or cultural historians, should pursue this research actively and in a matter-of-fact way. But they should also carry out investigations hand in hand with other experts. And perhaps even more important: the approach should be transnational from the outset. Only someone in a position to describe the collective emotions, the construction of identity, and the trauma linked to these issues on the side of the "perpetrators" as well as of the "victims" will be able to make a contribution that does justice to the complexities of the issue. Only those who understand the significance of the Pharaonic past for the newly autonomous Egypt of the 1920 s will also understand the meaning, for present-day Egyptians, of restitution claims for Nefertiti. And if one ignores how Nefertiti and Amarna Art were an integral part of the construction of the identity of the avant-garde and of social democracy in the Weimar Republic in Berlin of the 1920s - one will also be unable to understand why for many decades Berlin has stubbornly and awkwardly resisted restitution. 


\section{What Can Be Done?}

The history of these "displaced objects" is a political, legal and cultural history, one of possession, seizure, confiscation, sale, robbery, purchase, instrumentalization for the construction of identity - but also, frequently, the history of a free and fruitful intellectual acquisition resulting from the material acquisition. Contrary to their wishes, in the last fifteen years "provenance" has become a subject for art institutions, which do not have the necessary expertise for it. Yet the deep cultural and multi-layered implications linked to provenance are always kept in the dark, leading to an often intolerable simplification of history, to public misunderstandings fuelled by the media, a collapse of communication, and more. For this reason, the younger generation of art historians, who in the coming decades will be active on the art market and in museums, need to develop a sensorium for these complex questions. Among others, one way to encourage this would be to have academic training include in its programs "provenance research" and the issue of dealing with "displaced objects" in general. These fields should be a feature of art history seminars, at best in the context of transnational cooperation and from the start, in close collaboration with archives - the very heartbeat of our times. Finally, all the above also depends on the willingness of museums to discover and disclose the provenance of their holdings for the benefit of a public deeply interested in these issues. 